\title{
Konsep Wisata dari Perspektif Ekonomi Masyarakat
}

\author{
Tati Haryati ${ }^{1, *}$, A. Gafar Hidayat ${ }^{1}$ \\ ${ }^{1}$ STKIP Taman Siswa Bima \\ *tatiharyati031@gmai.com
}

\section{Artikel Info}

Tanggal Publikasi

2019-12-30

\section{$\underline{\text { Kata Kunci }}$}

Wisata

\section{Perpektif Ekonomi}

Masyarakat

\begin{abstract}
Abstrak
Tujuan penulisanini, yaitu untuk mendeskripsikan dan mengkaji konsep wisata dari sudut pandang ekonomi kemasyarakatan yang berkontribusi pada perkembangan ekonomi dan peningkatan kesejahteraan. Pariwisata merupakan salah satu kegiatan yang dilakukan oleh individu atau kelompo kmasyarakat untuk mendatangai tempat tertentu dalam jangka waktu yang terbatas, dengan harapan tempat yang dikunjungi dapat memberikan ketenagan jiwa, untuk merefresing pikiran dan tenaga melalui wahana permainan atau pesona pemandangan yang memberikan hiburan dan tontonan menarik. Alam juga dapat dijadikan tempat tujuan berwisata, yang menyediakan destinasi natural dan bukan dari buatan tangan manusia. Konsep wisata dari sudut pandang ekonomi kemasyarakatan, yaitu; (1) Pertumbuhan ekonomi melaju dengan cepat; Dengan adayanya aktivitas wisata dapatmerangsang pertumbuhan ekonomi dengan cepat, hal itu dapat dirasakan dengan banyaknya tercipta peluang usaha dan kesempatan kerja; (2) Tingkat kesejahteraan masyarakat meningkat; Kesejahteraan masyarakat menjadi meningkat akibat adanyaaktivitas wisata yaitu karna adanya peredaran uang yang cukup besar di tempat wisata sehingga banyaknya tercipta peluang dan kesempatan; (3) Kesenjangan antara pengusaha kecil dan pengusaha besar; Kesenjangan yang terjadi pada masyarakat setempat apabila permintaan wisata meningkat derastis, sehingga menarik minat pihak suwasta maupun asing untuk melakukan infestasi dan penanaman modal; (4) Kecilnya peluang dan kesempatan bagi masyarakat setempat; Hal ini terjadi apabila pihak suasta telah mendominasi, Kawasan wisata tersebut, karena perusahan besar selalu memperkerjakan orang-orang yang profesiaonal yang didatangankan dari luar daerah maupunluar negeri untuk meningkatkan efektivitas pendapatan dan nilai jual; (5) Dampak langsung bagi lingkungan dan ekosistem; Penebangan hutan untuk pembukaan lahan pembangunan infrasrukrur atau fasilitas penunjang pariwisata. Kemudian limbah yang dihasilkan dari aktifitas wisata alam apabila tidak dikelola dengan baik, makalingkungan mudah tercemar dan keseimbangan ekosistem bias terancam.
\end{abstract}

\section{PENDAHULUAN}

Perkembangan pariwisata sangat pesat dalam beberapa tahun belakangan ini. Banyak orang mulai menyadari akan pentingnya berwisata. Selama ini mereka hanya menghabiskan waktu untuk bekerja, sehingga tingkat stress pun akan meningkat. Oleh sebab itu, mereka mulai memanfaatkan waktu luang dengan melakukan perjalanan wisata untuk bersenang-senang dan melupakan sejenak rutinitas mereka. Apalagi keadaan ekonomi masyarakat saat ini semakin membaik, sehingga banyak orang dari berbagai golongan mampu untuk melakukan perjalanan wisata.

Menurut Ida Ayu (2011) Pariwisata merupakan salah satu sektor ekonomi yang tumbuh paling cepat dan merupakan salah satu industri terbesar di dunia. Pada tahun 1950 industri perjalanan (travel) mencatat 25 juta kedatangan internasional. Pada tahun 1980 angka ini telah meningkat menjadi 277 juta dan menjadi 438 juta pada tahun 1990 (tujuh belas kali lipat jika dibandingkan dengan tahun 1950). Pada awal abad ini terdapat 684 juta kedatangan internasional yang tercatat dan meningkat hingga 907 juta pada tahun 2007 dan 922 juta pada 
tahun 2008. Namun, untuk tahun 2009, diperkirakan angka kedatangan internasional secara kasar sejumlah 870 juta (delapan bulan pertama pada tahun 2009 tercatat 600 juta kedatangan internasional).

Lebih lanjutAryunda (2011) menyatakan secara umum ekowisata yang terjadi di Kepulauan Seribu menyebabkan dampak ekonomi yang positif bagi pengembangannya. Pernyataan masyarakat mengindikasikan terjadinya peningkatan dari segi pendapatan dan/atau usaha yang berkaitan dengan kegiatan ekowisata di Kepulauan Seribu. Selain itu, kegiatan ekowisata menyediakan lapangan pekerjaan yang cukup besar bagi masyarakat lokal maupun masyarakat di luar wilayah Kepulauan Seribu. Peningkatan pendapatan juga terjadi pada penerimaan daerah, terutama dari sektor perdagangan, hotel dan restoran. Perlu adanya pembenahan terhadap objek ekowisata dan pelatihan terhadap masyarakat lokal mengenai ekowisata yang berlangsung di daerahnya untuk meningkatkan minat dan daya tarik wisatawan untuk meningkatkan ekonomi lokal wilayah Kepulauan Seribu

Dunia pariwisata saat ini sedang gencar-gencarnya, dimana banyak daerah di Indonesia, saat ini sedang melakukan promosi besar-besaran tentang potensi wisata yang dimiliki dan bahkan negarapun ikut ambil andil melalui kementrian pariwisata untuk mempromosikan potensi wisata yang ada di indonesia pada dunia internasional. Pariwisata merupakan industri baru yang dapat meningkatkan pendapatan negara dan daerah, yang bergantung sungguh pada tingkat keindahan dan kelestarian lingkungan. Kelestarian lingkungan yang bersih, serta pemandangan yang indah dapat tercemar seketika dan meninggalkan bau, serta pemandangan yang tidak sedap, apabila pemanfaatannya tidak dikelola dengan baik, limbah atau sampah yang dihasilkan oleh pengunjung dapat berdampak buruk bagi petumbuhan ekosisten yang ada di daerah setempat. Oleh karena itu pengelola pariwisata maupun pemerintah, harus bermitra dengan seluruh stekholder lainnya untuk menjaga kelestarian lingkungan, supaya terjadi keseimbangan ekosistem.

Tanpa lingkungan yang baik tidak mungkin pariwisata berkembang. Oleh karena itu dalam pengembanga pariwisata haruslah memperhatiakan mutu lingkungan, sebab dalam dunia pariwisata mutu lingkungan itulah yang ingin dijual untuk menarik wisatawan. Pengelolaan lingkungan perlu diperhatiakan dengan baik untuk terciptanya kelestarian dan keseimbangan lingkungan, guna mendukung pembangunan secara berkelanjutan di bidang pariwisata dalam program pembangunan jangka pendek, menengah maupun jangka panjang.

Pembangunan pariwisata merupakan salah satu pembanguanan yang perlu dikembangkan karena sektor ini dapat meningkatkan penerimaan devisa negara, menghasilkan pertumbuhan ekonomi dengan cepat dalam ketersediaan lapangan kerja, peningkatan penghasilan, peningkatan pola hidup, serta menstumulus berbagai faktor pengembangan produksi. Oleh karena itu muncul berbagai kegiatan ekonomi diwilayah/kawasan wisata seperti; pembangunan hotel dan penginapan, restoran, industri kerajinan tangan sebagai oleh-oleh khas daerah, jasa menjadi guide, warung/toko sembako, jasa travel dan fasilitas pendukung lainya.

Keberadaan sektor pariwisata disuatu daerah harus didukung oleh semua pihak, mulaui dari peerintah, masyarakat setempat serta pihak suwasta yang akan menanamkan modal untuk pengembangan sektor wisata, supaya tidak terjadi hal-hal yang tidak di inginkan dikemudian hari, apalagi menyangkut keselamatan dan kenyamanan wisatawan yang datang dari berbgai daerah maupun mancan negara. Secara finansial dunia pariwisata terutama pada bidang wisata alam dapat memberikan kontribusi nyata bagi pemerintah dan masyarakat, untuk mencitakan berbagai peluang usaha dan mengurangi tingkat pengangguran, sehingga mampu menyejahterakan masyarakat setempat.

Kecenderungan pariwisata memiliki landasan dalam perubahan-perubahan mendasar pada hampir seluruh dimensi kegiatan pariwisata yang meliputi perubahan lingkungan ekonomi dan politik global, perubahan profil demografis dan psikografis wisatawan, perubahan manajamen dan perubahan teknologi. Ini menunjukkan bahwa selain merupakan penyumbang devisa dan pembuka lapangan pekerjaan, pariwisata juga mempunyai keterkaitan dengan berbagai sektor-sektor lainnya di luar sektor pariwisata. Sektor pariwisata mencakup berbagai kegiatan perekonomian yang dapat mendorong laju pertumbuhan sektor-sektor tersebut. Kegiatan pariwisata akan menimbulkan permintaan akan barang dan jasa sehingga akan merangsang pertumbuhan produksi. Semakin banyak permintaan wisatawan maupun industri pariwisata, maka akan dapat semakin membangunkan produktifitas sektor-sektor ekonomi.

Pariwisata mempunyai kekuatan sinergik, karena memiliki keterkaitan yang erat sekali dengan berbagai bidang. Pariwisata berkembang dan maju bersama dengan membawa bidang-bidang dan sektor-sektor 
pembangunan lainnya, mulai dari perhubungan, pertanian, lingkungan hidup, kualitas sumber daya manusia yang handal dan bidang-bidang yang lainnya. Dalam konteks ini pariwisata menjadi faktor sinergis dalam memacu gerak ekonomi bagi sebuah negara, baik secara nasional, sektoral, maupun lokal (Sutowo, 2000).

Menurut Davydd J.Greenwood bahwa adanya kunjungan wisatwan disuatu tempat menyebabkan terjadinya suatu interaksi sosial antara masyarakat sekitar dengan wisatawan yang dapat mengakibatkan perubahan pola, atau tata cara hidup masyarakat. Selain menyebakan masalah aspek sosial, juga berdampak pada aspek ekonomi yaitu terbukanya peluang atau kesempatan kerja yang dapat meningkatkan pendapatan masyarakat (Liu, Wang, Wang, Wang, \& Deng, 2018).

Aktivitas wisata yang berkembang saat ini menjanjikan hasil yang begitu besar bagi daerah maupun masyarakat, dalam hal pendapatan dari biaya yang dikeluarkan oleh para wisatawan yang berasal dari berbagai daerah maupun mancan negara, menjadi perangsan pertumbuhan ekonomi, dimana produksi akan barang dan jasa menjadi meningkat. Namun tidak dapat dihindari sebagai dampak dari pariwista dapat mencemari lingkungan sekitar, serta pola dan cara hidup masyarakat, yang mulai berubah akibat dari interaksi antara penduduk setempat dengan wisatawan akan mengikis nilai tradisi dan budaya yang sudah ada, dan tidak menutup kemungkinan terjadinya akulturasi, sehingga masyarakat sekitar pariwisata sulit untuk mempertahankan nilai budaya sebagai warisan leluhur, sehngga generasi yang akan datang kehilangan identitas budayanya.

Masyarakat yang ada di daerah lokal lebih cenderung meniru hal baru yang mereka lihat sebagai identitas pembaharuan yang nantinya secara berlahan akan mulai meninggalkan budaya serta kebiasaan sendiri, sehingga mulailah terjadinya pergeseran nilai-nilai sosial budaya yang ada di masyarakat. Secara tidak langsung budaya baru menyentuh seluruh aspek penting kehidupan, menciptakan berbagai tantangan dan permasalahan baru yang harus dijawab, dipecahkan dalam upaya menjaga kemurnian budaya asli suatu daerah.

Pada dasarnya budaya atau tradisi kebiasaan masyarakat memiliki sifat yang dinamis, jadi selalu berubah guna menyesuaikan diri dengan keadaan lingkungan, semakin canggih suatu zaman maka semakin kompleks pula kehidupan manusia yang mulai menunjukan perubahan dalam hidupnya. Pembauran yang terjadi antara dua budaya berbeda biasanya terjadi karena berbagai faktor, salah satu penyebababnya adalah akibat dari adanya kegiatan wisata.

Menurut Cao dkk., (2016) Dengan meningkatnya populasi manusia dan urbanisasi, pariwisata di cagar alam dan lahan lindung lainnya tumbuh. Sangat penting untuk memantau dan menilai dampak pariwisata terhadap kesehatan ekosistem. Namun, ada kurangnya informasi umum tentang komunitas biologis di cagar alam negara berkembang dan belum tersedianya alternatif untuk menangani dampak bagi masyarakat setempat. Hal ini yang belum dipikirkan oleh pengembang/pengelola dunia wisata.

Indonesia terkenal sebagai wilayah yang kaya akan hasil dan keindahan alamnya yang begitu melimpah, hal tersebut yang menarik minat para wisatawan baik lokal maupun mancan negara, sengaja datang ke Indonesia untuk berwisata. Perubahan yang terjadi pada generasi muda dewasa ini, pada dasarnya mereka meniru gaya berpakaian serta cara hidup yang dilihat dari luar daerahnya, sehingga mereka meniru, kebiasan tersebut menjadi bagian dalam kehidupannya dan di praktekkan pada kelangsungan kehidupan sehari-hari. Adanya perubahan sikap dan kebiasaan pada generasi muda, mengakibatkan pudarnya nilai-nilai budaya, hal itu terjadi karena generasi muda adalah generasi penerus bangsa, maka dari itu adanya perubahan kebiasaan dan tradisi dalam masyarakat yang mengarah pada pergeseran nilai sosial budaya disebabkan oleh generasi muda.

Menurut Koentjoroningrat (1990) bahwa pergeseran nilai budaya adalah perubahan-perubahan yang mencakup unsur-unsur kebudayaan, yakni mencakup perubahan sistim pengetahuan, organisasi sosial, sistim mata pencaharian, sistim teknologi, religi, bahasa dan kesenian. Perubahan ini terjadi akibat ketidak sesuaian di antara unsur-unsur kebudayaan yang saling berbeda sehingga menghasilkan suatu keadaan yang harmonis bagi kehidupan.

Perubahan sosial budaya adalah perubahan yang mencakup hampir semua aspek kehidupan sosial dan budaya dari suatu masyarakat atau komunitas. Pada hakekatnya, proses ini lebih cenderung pada proses penerimaan perubahan baru yang dilakukan oleh masyarakat tersebut guna meningkatkan taraf hidup dan kualitas kehidupannya. Meskipun demikian, perubahan sosial budaya tidaklah lepas dari penilaian tentang dampak positif dan negatif dari responden yang mengalami proses ini secara langsung. Perubahan yang terjadi 
dalam kehidupan masyarakat saat ini buka saja sebagai dampak dari adanya perkembangan dunia pariwisata saja, juga tidak luput dari pengaruh globalisasi yang menyajikan informasi dari berbagai daerah, sehingga informasi yang diperoleh dipandang sebagai modernisasi, sewalaupun bertentengan dengan kebiasaan tradisi sendiri yang mengakibatkan pergeseran nilai sosial budaya.

Wisata yang terdapat di daerah seluruh Indonesia saat ini, sedang dikembangkan secara efektif dan mendapat perhatian dari pihak pemerintah dan swasta untuk berkontribusi nyata dalam penenaman modal, hal itu dilakukan serta merta dengan tujuan meningkatkan kesejahteraan masyarakat setempat, mengurangi tinggkat pengangguran, pembangunan infrastruktur pendukung seperti jalan menuju lokasi wisata, dan masih banyak kontribusi wisata lainnya bagi kelangsungan kehidupan masyarakat setempat. Kawasan wisata menjadi industri non produk bagi pemerintah daerah maupun pusat, untuk mendongkrak pendapatan daerah melaui pajak dan visa, sehingga keindahan alam atau potensi wisata yang dimiliki oleh suatu daerah harus diekspost salah satu contohnya wisata alam yang ada di Raja Ampar Papua Barat, tidak tanggung-tanggung pemerintah daerah mengajak seluruh wisatawan untuk berwisata di daerahnya, melaui iklan ditelevisi dan media sosial. Namun yang perlu dipikirkan yaitu dampak negatif dari adanya wisata alam yang dapat merusak keseimbangan ekosistem yang ada di daerah tersebut, serta kondisi masyarakat setempat perlu diperhatikan dengan baik, agar perencanaan jangka panjang terhadap pelaksaan pariwisata dapat terjaga keasriannya dalam waktu yang cukup lama dan dapat diwariskan pada generasi selanjutnya.

Adapun tujuan penulisan ini, yaitu untuk mendeskripsikan dan mengkaji konsep wisata dari sudut pandang ekonomi kemasyarakatan yang berkontribusi pada perkembangan ekonomi dan peningkatan kesejahteraan

\section{HASIL DAN PEMBAHASAN}

\section{AktifitasWisata}

Wisata atau yang dikenal dengan istilah pariwisata merupakan salah satu kegiatan yang dilakukan oleh individu atau kelompok masyarakat untuk mendatangai tempat tertentu dalam jangka waktu yang terbatas, dengan harapan tempat yang dikunjungi dapa memberikan ketenagan jiwa, untuk merefresing pikiran dan tenaga melalui wahana permainan atau pesonana pemandangan yang memberikan hiburan dan tontonan menarik. Wisata dapat di simpulkan sebagai aktivitas mengunjungi sutu tempat dengan tujuan berwisata, yang berhubungan dengan pemandangan atau destinasi alam natural dan bukan dari buatan tangan manusia, namun disekitar lokasi wisata terdapat beberapa fasilitas pendukung hasil dari pemikiran manusia, untuk memberikan pelayanan dan kepuasan terhadap wisatawan.

Dalam Undang-Undang No. 10 Tahun 2009 tentang kepariwisataan yang terdiri atas tujuh belas bab dan tujuh puluh pasal yang mengandung ketentuan meliputi delapan hal, yaitu:

1) Wisata adalah kegiatan perjalanan yang dilakukan oleh seseorang atau sekelompok orang dengan mengunjungi tempat tertentu untuk tujuan rekreasi, pengembangan pribadi atau mempelajari keunikan daya tarik wisata yang dikunjungi dalam jangka waktu sementara.

2) Wisatawan adalah orang yang melakukan wisata.

3) Pariwisata adalah berbagai macam kegiatan wisata dan didukung berbagai fasilitas serta layanan yang disediakan oleh masyarakat, pengusaha, pemerintah dan pemerintah daerah.

4) Kepariwisataan adalah keseluruhan kegiatan yang terkait dengan pariwisata dan bersifat multidimensi serta multidisiplin yang muncul sebagai wujud kebutuhan setiap orang dan negara serta interaksi antara wisatawan, pemerintah, pemerintah daerah dan pengusaha.

5) Daya tarik wisata adalah segala sesuatu yang memiliki keunikan, keindahan, dan nilai yang berupa keanekaragaman kekayaan alam, budaya, dan hasil buatan manusia yang menjadi sasaran atau tujuan kunjungan wisatawan.

6) Daerah tujuan pariwisata yang selanjutnya disebut destinasi pariwisata adalah kawasan geografis yang berada dalam satu atau lebih wilayah administratif yang didalamnya terdapat daya tarik wisata, fasilitas umum, fasilitas bpariwisata, aksesibilitas, serta masyarakat yang saling terkait dan melengkapi terwujudnya kepariwisataan. 
7) Usaha pariwisata adalah usaha yang menyediakan barang dan atau jasa bagi pemenuhan kebutuhan wisatawan dan penyelenggaraan pariwisata.

8) Pengusaha pariwisata adalah orang atau sekelompok orang yang melakukan kegiatan usaha pariwisata.

Menurut Guyer Freuler menjelaskan pengertian pariwisata merupakan fenomena kebutuhan akan kesehatan dan pergantian suasana, penilaian yang sadar dan menumbuhkan (cinta) terhadap keindahan alam dan khususnya bertambahnya pergaulan berbagai bangsa dan kelas masyarakat manusia sebagai hasil daripada perkembangan perniagaan, industri, perdagangan, serta penyempurnaan dari alat-alat pengangkutan (MacNeill \& Wozniak, 2018a).

Dari uraian tersebut dapat dipahami bahwa pariwisata merupakan bagian dari kebutuhan manusia yang mnginginkan, adanya keindahan, kenyamana, keasrian dan ketenanan jiwa, melaui objek pemandangan dan destinasi keindahan alam. Dalam hal ini tujuan seseorang berpariwisata tidakan hanya sebatas memenuhi rasa akan keindahan destinasi alam, terdapat juga $3 \mathrm{~W}$ beberapa diantaranya memanfaatkan destinasi keindahan alam untu terapi kesehatan dan kestabilan mental.

Hakikatnya berpariwisata adalah suatu proses kepergian sementara dari seseorang atau menuju tempat lain di luar tempat tinggalnya. Dorongan kepergiannya adalah karena berbagai kepentingan, baik karena kepentingan ekonomi, sosial, kebudayaan, politik, agama, kesehatan maupun kepentingan lain seperti sekedar ingin tahu, menambah pengalaman ataupun untuk belajar. Menurut Spillane, Pariwisata adalah perlajanan dari satu tempat ke tempat lain, bersifat sementara, dilakukan perorangan maupun kelompok, sebagai usaha mencari keseimbangan atau keserasian dan kebahagiaan dengan lingkungan hidup dalam dimensi sosial, budaya, alam, dan ilmu. World Tourism Organization (WTO) pariwisata adalah kegiatan seseorang yang bepergian atau tinggal di suatu tempat di luar lingkungannya yang biasa dalam waktu tidak lebih dari satu tahun secara terus menerus, untuk kesenangan, bisnis ataupun tujuan lainnya (Seraphin, Sheeran, \& Pilato, 2018).

Menurut Yoeti (2008) Pariwisata adalah suatu aktivitas manusia yang dilakukan secara sadar yang mendapat pelayanan secara bergantian diantara orang-orang dalam suatu negara itu sendiri atau diluar negeri, meliputi pendiaman orang-orang dari daerah lain untuk sementara waktu mencari kepuasan yang beraneka ragam dan berbeda dengan apa yang dialaminya, dimana ia memperoleh pekerjaan tetap.

Undang-Undang No. 23 tahun 2014 tentang pembaharuan Konservasi Sumberdaya Alam Hayati dan Ekosistemnya, Taman Wisata Alam adalah kawasan pelestarian alam yang terutama dimanfaatkan untuk pariwisata dan rekreasi alam. Sedangkan kawasan konservasi sendiri adalah kawasan dengan ciri khas tertentu, baik di darat maupun di perairan yang mempunyai sistem penyangga kehidupan, peng-awetan keanekaragaman jenis tumbuhan dan satwa, serta pemanfaatan secara lestari sumberdaya alam hayati dan ekosistemnya.

Wisata alam adalah bentuk kegiatan rekreasi dan pariwisata yang memanfaatkan potensi sumberdaya alam, baik dalam keadaan alami maupun setelah ada usaha budidaya, sehingga memungkinkan wisatawan memperoleh kesegaran jasmaniah dan rohaniah, mendapatkan pengetahuan dan pengalaman serta menumbuhkan inspirasi dan cinta terhadap alam.

Pengertian pariwisata menurut A.J Burkat dalam Damanik (2006) parwisata adalah perpindahan orang untuk sementara dan dalam jangka waktu pendek ke tujuan-tujuan diluar tempat dimana mereka biasa hidup dan bekerja dan juga kegiatan-kegiatan mereka selama tinggal di suatu tempat tujuan. Selanjutnya pendapat yang dikemukakan oleh (Yoeti, 2008) Pariwisata berasal dari dua kata yaitu Pari dan Wisata. Pari dapat diartikan sebagai banyak, berkali-kali, berputar-putar atau lengkap. Sedangkan Wisata dapat diartikan sebagi perjalanan atau bepergian yang dalam hal ini sinonim dengan kata reavel dalam bahasa Inggris. Atas dasar itu maka kata pariwisata dapat juga diartikan sebagai perjalanan yang dilakukan berkali-kali atau berputar-putar dari suatun tempat ketempat yang lain yang dalam bahsa Inggris didebut juga dengan istilah Tour.

Menurut Mill dan Morisson dalam Okumus, van Niekerk, Koseoglu, \& Bilgihan (2018). Ada bebrapa variabel sosioekonomi yang mempengaruhi permintaan pariwisata, yaitu sebagai berikut:

a. Umur

Hubungan antara pariwisata dan juga umur mempunyai dua komponen yaitu besarnya waktu luang dan aktifitas yang berhubungan dengan tingkatan umur tersebut. Terdapat juga beberapa perbedaan pola konsumsi antara kelompok yang lebih tua dengan kelompok yang lebih muda. 
b. Pendapatan

Pendapatan merupakan faktor terpenting dalam membentuk permintaan untuk mengadakan sebuah perjalanan wisata. Bukan hanya perjalanan itu sendiri yang memakan biaya wistawan juga harus mengeluarkan uang untuk jasa yang terdpat pada tujuan wisata dan juga di semua aktifitas selama mengadakan perjalanan.

c. Pendidikan

Tingkat pendidikan mempengaruhi tipe dari waktu yang luang untuk digunakan dalam perjalanan yang dipilih. Selain itu juga pendidikan merupakan suatu motivasi untuk melakuakan perjalanan wisata. dapat juga dismpulkan bahwa tingkat pendidikan mempengaruhi pandangan seseorang dan memberikan lebih banyak pilihan yang bisa diambil oleh seseorang.

Menurut Marpaung (2002) obyek dan daya tarik wisata adalah suatu bentuk dari aktifitas dan fasilitas yang berhubungan, yang menarik minat wisatawan atu pengunjung untuk datang ke suatu daerah atau tempat tertentu. Obyek dan daya tarik wisata sangat erat hubungannya dengan travel motivationdan travel fasion, karena wisatawan ingin mendapatkan suatu pengalamn tertentu dalam kunjungannya ke suatu obyek wisata.

Berdasarkan Pengertian pariwisata yang diuraikan sebelumnya, maka dapat disimpulkan bahwa kegiatan pariwisata mempunyai ciri-ciri sebagai berikut:

1) Terdapat dua lokasi yang saling terkait yaitu daerah asal dan juga daerah tujuan (destinasi).

2) Sebagai daerah tujuan pasti memiliki objek dan juga daya tarik wisata.

3) Sebagai daerah tujuan pasti memiliki sarana dan prasarana pariwisata.

4) Pelaksana perjalananan ke daerah tujuan dilakukan dalam waktu sementara.

5) Terdapat dampak yang ditimbulkan, khususnya daerah tujuan, dari segi sosial budaya, ekonomi dan lingkungan.

\section{Kontibusi Wisata Dibidang Ekonomi}

Dunia pariwisata yang lebih dikenal saat ini senagai industi pariwisata yang menghasilkan pelayanan dan jasa, yang dikelola oleh pemerintah daerah, pemerintah pusat maupun pihak suwasta, memiliki peran penting dalam pertumbuhan ekonomi. Pariwisata dapat dijadikan sebagai motor penggerak roda perekonomian yang cukup penting bagi peningkatan kesejahteraan masyarakat, terutama masyarakat yang ada di sekitar lokasi wisata. Hal ini sudah bukan menjadi rahasia publik lagi bahwa pariwisata dapat menyejahterakan masyarakat setempat, dan dapat menjalankan roda perekonomian dibidang jasa dan pelayanan, terutama dibidang kuliner. Masyarakat yang ada disekitar lokasi wisata alam biasanya menjami para wisatwan baik domestik maaupun internasional, dengan kuliner khas yang ada di daerah tersebut, dan harganyapun ditentukan oleh penjual, karna kuliner yang ditawarkan tidak terdapat ditempat lainnya.

Dunia pariwisata dapat menciptakan lapangan kerja baru, dan mapun menurunkan angka jumlah pengangguran yang ada di suatu daerah. Hal itu terjadi karena masyarakat dibuatnya kreatif dengan menyediakan berbagai wana menari yang dipertontonkan kepada para wisatwan, selai itu jasa menjadi travel, guide, dan lain sebagainya. Dengan terciptanya lapangan kerja baru, secara otomatis berkurang angka pengangguran dan tingkat kesejahteraan akan meningkat. Pemerintah daerah dan pusat, mengatur sedemikian rupa untuk menghasikan kegiatan wisata yang memberi dampak besar terdap perekonomian, dengan memperhatikan kesimbangan ekosistem yang terdapat di daerah wisata. Dengan kata lain Pariwisata dapat menjadi devisa bagi negara, sehingga dapat meningkatkan perekonomian.

Namun ada hal yang perlu dihawatirkan dari aktivitas wisata dalam bidang ekonomi, karena tingginya permintaan berwisata sehinga, menyebakan pihak suwasta bahkan asing datang melakukan investasi, dengan menyiapkan fasilitas pendukung yang serba mewah dan menggunakan teknologi canggih, sehingga masyarakat setempat kalah bersaing dan keuntungan hanya dinikmati oleh sebahagian orang atau kelompok pendatang saja. $\mathrm{Hal}$ ini dapat menyebabkan keterpurukan dan kesenjangan ekonomi bagi masyarakat setempat. Menghindari hal tersebut pemerintah dan pihak suwasta yang ingin melakukan investasi di tempat ekowisata tersebut, haruslah diatur dengan baik dan bermitra dengan masyarakat setempat untuk melakukan pengawasan. 
Salah satu sasaran yang hendak dicapai dalam pembangunan nasional adalah suatu pertumbuhan ekonomi yang dapat mempercepat peningkatan pendapatan dan kesempatan kerja. Hal ini berarti bahwa pembangunan ekonomi diarahkan pada pendayagunaan sumber daya alam dan sumber daya manusia seefisien dan seefektif mungkin sehingga menghasilkan produksi yang dapat meningkatkan kesejahteraan masyarakat. Pembangunan adalah suatu proses multidimensional yang meliputi perubahan dasar atas struktur sosial dan sikap masyarakat serta institusi-institusi nasional disamping tetap mengejar percepatan pertumbuhan ekonomi, mengatasi kesenjangan pendapatan dan hasil-hasil pembangunan serta mengurangi kasus kemiskinan (Todaro, 2000).

Menurut Wahab dalam Yoeti (2008) Pariwisata merupakan faktor penting dalam pembangunan ekonomi suatu Negara, karena mendorong perkembangan beberapa sektor perekonomian nasional, misalnya:

1) Peningkatan kegiatan perekonomian sebagai akibat dibangunnya sarana dan prasarana demi pengembangan pariwisata, sehingga memungkinkan orang- orang melakukan aktivitas ekonominya dari suatu tempat ke tempat lainnya, baik dalam satu wilayah Negara tertentu, maupun dalam kawasan internasional sekalipun.

2) Meningkatkan industri-industri baru yang erat kaitannya dengan pariwisata seperti misalnya, transportasi, akomodasi (hotel, motel, vila, restoran, dan lain-lain) yang akan menciptakan permintaan-permintaan baru bagi wisatawan.

3) Meningkatkan hasil pertanian dan peternakan untuk kebutuhan hotel dan restoran seperti sayur, buahbuahan, telur, daging, dan lain-lain karena semakin banyaknya orang-orang yang melakukan perjalanan wisata.

4) Meningkatkan permintaan terhadap: handicrafts, souvenir, goods, art painting, dann lain-lain..

5) Memperluas barang-barang lokal untuk lebih dikenal oleh dunia internasional termasuk makanan dan minuman, barang-barang kerajinan seperti: ukiran Jepara, patung Bali, batik Pekalongan, sulaman Tasikmalaya, dan lain sebagainya.

6) Meningkatkan perolehan devisa negara, sehingga dapat mengurangi beban devisit neraca pembayaran.

7) Memberikan kesempatan berusaha, kesempatan kerja, peningkatan penerimaan pajak bagi pemerintah, dan peningkatan pendapatan nasional.

8) Membantu membangun daerah-daerah terpencil yang selama ini tidak tersentuh pembangunan.

9) Mempercepat perputaran perekonomian pada Negara-negara penerima kunjungan wisatawan (Tourist Receiving Countries).

10)Dampak penggandaan yang ditimbulkan pengeluaran wisatawan, sehingga member dampak positif bagi pertumbuhan daerah tujuan wisata (DTW) yang dikunjungi wisatawan.

Wisatawan yang datang berkunjung pada suatu negara atau daerah tempat wisata merupakan sumber pendapatan dan sekaligus juga berfungsi sebagai alat pemerataan bagi penduduk suatu daerah dan Negara, sedikitnya bagi orang-orang dalam bisnis pariwisata tersebut yang dapat dikunjungi. Setelah wisatawan datang pada suatu daerah wisatawan, mereka pasti akan membelanjakan uangnya pada perusahaan-perusahaan atau kelompok industri lokal, dan lain sebagainya untuk memenuhi kebutuhan dan keinginan selama mereka tinggal di daerah tersebut. Uang yang dibelanjakan oleh wisatawan itu, setelah dibelanjakan tidak berhenti beredar, akan tetapi berpindah dari satu tangan ke tangan orang lain atau dari satu perusahaan ke perusahaan lainnya, untuk menunjang berputarnya roda perekonomin. Hal ini akan menciptakan keterkaitan berbagai sektor terhadap sektor pariwisata. Hal yang perlu diketahui bahwa penglipatgandaan yang terjadi tidak sama, akan tetapi bervariasi dari suatu sektor ke sektor lainnya.

Selain keuntungan-keuntunganyang diperoleh dari pariwisata, terdapat dampak yang merugikan bagi masyarakat di antaranya sebagai berikut:

1) Bahaya ketergantungan terhadap industri pariwisata. Beberapa daerah tujuan wisata menjadi sangat tergantung dari kepariwisataan untuk kehidupannya. Hal ini menjadikan wisatawan sangat rentan terhadap perubahan permintaan wisata. Pariwisata merupakan industri yang dipengaruhi oleh banyak hal, seperti 
harga, gaya hidup, politik, dan ketersediaan energi. Apabila faktor-faktor itu mengganggu kepariwisataan, maka masyarakat yang menggantungkan hidup pada pariwisata akan terganggu.

2) Peningkatan inflasi dan nilai lahan. Ada kemungkinan lain yang membawa kehidupan masyarakat di daerah tujuan wisata menjadi lebih buruk. Inflasi dan peningkatan nilai lahan di daerah tujuan wisata menjadi konsekuensi dari pengembangan pariwisata. Resiko wisatawan membeli lahan dengan harga yang tinggi menjadi ancaman bagi masyarakat setempat. Harga di daerah tujuan wisata menjadi berkali-kali lipat karena wisatawan mampu membeli dengan harga yang lebih tinggi. Masyarakat pun harus menguras uang yang lebih dalam untuk mendapatkan kebutuhannya.

3) Peningkatan frekuensi impor. Wisatawan datang dari berbagai negara yang membawa kebiasaan sehari-hari ke destinasi wisata sehingga penyedia jasa dan produk wisata harus menyesuaikan dan menyediakan kebutuhan tersebut. Akibatnya, pengusaha pariwisata harus mengimpor produk dan jasa yang dibutuhkan oleh wisatawan. Sebagai contoh, wisatawan Eropa terbiasa minum anggur, sementara Indonesia bukan negara penghasil minuman tersebut sehingga pengusaha pariwisata harus mengimpor dari negara di tempat produk tersebut dihasilkan.

4) Produk musiman. Sifat pariwisata tergantung dari musim. Ketika musim sepi kunjungan, wisatawan jarang berkunjung sehingga penghasilan penduduk berkurang. Produsen yang mengandalkan kehidupan penjualannya sepenuhnya di industri pariwisata akan mengalami masalah keuangan.

5) Pengembalian modal lambat Industri pariwisata merupakan industri dengan investasi yang besar dan pengembalian modal yang lambat. Hal ini menyebabkan kesulitan bagi pengusaha pariwisata dalam mendapatkan pinjaman untuk modal usaha.

6) Mendorong timbulnya biaya eksternal lain. Pengembangan pariwisata menyebabkan munculnya biaya eksternal lain bagi penduduk di daerah tujuan wisata, seperti biaya kebersihan lingkungan, biaya pemeliharaan lingkungan yang rusak akibat aktivitas wisata, dan biaya peluang lain.

Dari beberapa uraian sebelumnya dapat di petakan bahwa dampak aktivitas wisata alam terhadap perekonomian yaitu sebagagai berikut:

1) Pertumbuhan ekonomi melaju dengan cepat.

Dengan adayanya kativitas wisata dapat merangsang pertumbuhan ekonomi dengan cepat, hal itu dapat dirasakan dengan banyaknya tercipta peluang usaha dan kesempatan kerja. Industri pariwisata sebagai slah satu alternatih pengegrak roda perekonomian dunia, begitupun di negara indonesia, kunjungan wisatwan dapat dijadikan sebagai devisa bagi negara untuk menambah pendapatan melaui pajak dan diipergunakan untuk pembangunan infrasturktur dan fasilitas pendukung

2) Tingkat kesejahteraan masyarakat meningkat

Kesejahteraan masyarakat menjadi meningkat akibat adanya aktivitas wisata yaitu karna adanya peredaran uang yang cukup besar di tempat wisata sehingga banyaknya tercipta peluang dan kesempatan. Masyarakat yang sebelumnya tidak memiliki pekerjaan tetap dapat melakukan sesuatu, yang dibutuhkan oleh wisatwan dilikasi, bisa saja dengan menjaul barang dan jasa, menjadi tenaga guide/pemandu wisata, bahkan masyarakat dibuat lebih kreatif dengan memanfaatkan potensi yang ada di alam sekitar untuk dijadikan kuliner khas ataun oleh-oleh khas, berupa ukiran dan sebagainya.

3) Kesenjangan antara pengusaha kecil dan pengusaha besar

Kesenjangan yang terjadi pada masyarakat setempat apabila permintaan wisata meningkat derastis, sehingga menarik minat pihak suwasta maupun asing untuk melakukan infestasi dan penanaman modal. Biasanya pengusaha besar selalu menggunakan alat canggih dan berteknologi tinggi, untuk membutuh persingan dengan pengusaha kecil. Biar bagaimanapun para wisatawan datang ke lokasi wisata mereka membutuhkan kenyamanan dan keindahan apalagi dimanjakan dengan teknologi, sehingga akan lebih banyak pendatang menginap dan menikmati wahana yang disajikan oleh perusahahaan besar, dan berdampak pada pengusaha kecil yang tidak mampu bersaing dan akhirnya gulung tikar. 
4) Kecilnya peluang dan kesempatan bagi masyarakat setempat

Hal ini terjadi apabila pihak suasta telah mendominasi, kawasan wisata tersebut, karena perusahan besar selalu memperkerjakan orang-orang yang profesiaonal yang didatangankan dari luar daerah maupun luar negeri untuk meningkatkan efektivitas pendapatan dan nilai jual. Hal ini bisa melemahkan bahkan kecil kemungkinan bagi masyarakat setempat untuk mendapatkan kesempatan kerja. Kesempatan kerja yang kurang dan tidak memadai dapat memicu terjadinya keterpurukan ekonmi bagi masyarakat setempat.

\section{KESIMPULAN}

Aktivitas wisata memiliki kontribusi bagi perkembangan dan pertumbuhan perekonomian baik, ditingkat daerah maupun penemerintah pusat, karena dengan adanya permintaan berwisata dapat meningkatkan devisa sumber pendapatan negara. Perputaran roda ekonomi semakin cepat dengan adanya aktivitas wisata, sehingga dunia pariwisata dapat disebut dengan istilah industri yang menyajikan jasa, nonbarang.

Disi lain wisata juga bisa membuat perekonomian masyarakat setemapat menjadi terpuruk apabila pemerintah dangan pihak suwasta dan masyarakat tidak bermitra dengan baik, serta perlu adaya kegiatan pengawasan untuk melindungi pengusaha kecil yang ada disekitar lokasi wisata.

Tidak hanya dibidang ekonomi dibidang lingkungan dan sosial budaya juga mendapat pengaruh yang begitu besar dan bisa saja terjdinya kesenjangan, karena kerusakan lingkungan akibat aktivitas wisata tidak dapat dihindari, karena akan ada perluasan lahan untuk membangun infrastruktur dan sebagainya.

Selanjutnya pada bidang sosial budaya, masyarakat sekitar tempat wisata, melakukan berbagai interaksi dengan pengunjung, sehingga masyarakat lokal terutama generasi muda, sangat rentan akan perubahan dan pembauran, dapat meniru kebiasaan yang berbeda dari para wisatawan, sehingga menyebabkan pergeseran nilainilai sosial dan budaya.

\section{Daftar Pustaka}

Aryunda, H. (2011). Dampak Ekonomi Pengembangan Kawasan Ekowisata Kepulauan Seribu. Journal of Regional and City Planning, 22(1), 1-16.

Cao, Y., Wang, B., Zhang, J., Wang, L., Pan, Y., Wang, Q., ... Deng, G. (2016). Lake macroinvertebrate assemblages and relationship with natural environment and tourism stress in Jiuzhaigou Natural Reserve, China. Ecological Indicators, 62, 182-190. https://doi.org/10.1016/j.ecolind.2015.11.023

Ida Ayu. (2011). Dampak Pengeluaran Wisata Terhadap Pertumbuhan Ekonomi. UNDIP O-JS, vol.2, 199-208.

Koentjoroningrat. (1990). Pengantar Ilmu Antropologi. Jakarta: Rineka Cipta.

Liu, J., Wang, J., Wang, S., Wang, J., \& Deng, G. (2018). Analysis and simulation of the spatiotemporal evolution pattern of tourism lands at the Natural World Heritage Site Jiuzhaigou, China. Habitat International, 79, 74-88. https://doi.org/10.1016/j.habitatint.2018.07.005

MacNeill, T., \& Wozniak, D. (2018a). The Economic, Social, And Environmental Impacts Of Cruise Tourism. Tourism Management, 66, 387-404. https://doi.org/10.1016/j.tourman.2017.11.002

(2018b). The Economic, Social, And Environmental Impacts Of Cruise Tourism. Tourism Management, 66, 387-404. https://doi.org/10.1016/j.tourman.2017.11.002

Oktaviyanti, S. S. (2013). Dampak Sosial Budaya Interaksi Wisatawan dengan Masyarakat Lokal di Kawasan Sosrowijayan. Jurnal Nasional Pariwisata, 5(3), 201-208.

Okumus, F., van Niekerk, M., Koseoglu, M. A., \& Bilgihan, A. (2018). Interdisciplinary Research In Tourism. Tourism Management, 69, 540-549. https://doi.org/10.1016/j.tourman.2018.05.016

Prayogi, P. A. (2011). Dampak Perkembangan Pariwisata Di Objek Wisata Penglipuran. Jurnal Perhotelan Dan Pariwisata, 1(1), 64-79.

Qomarudin. (2013). Perubahan Sosial Dan Peran Masyarakat Dalam Pengembangan Kawasan Wisata Kepulauan Karimunjawa. Educational Sosial Studies, Volume 2, 41-46. 
Ranjabar, J. (2015). Perubahan Sosial: Teori-Teori dan Proses Perubahan Sosial serta Teori Pembangunan. Bandung: Alfabeta.

Rosana, E. (2011). Modernisasi dan Perubahan Sosial. Jurnal TAPIs, 7(1), 46-62.

Seraphin, H., Sheeran, P., \& Pilato, M. (2018). Over-tourism And The Fall Of Venice As A Destination. Journal of Destination Marketing $\mathcal{E}$ Management, 9, 374-376. https://doi.org/10.1016/j.jdmm.2018.01.011

Stefănica, M., \& Butnaru, G. I. (2015). Research on Tourists' Perception of the Relationship between Tourism and Environment. Procedia Economics and Finance, 20, 595-600. https://doi.org/10.1016/S2212. $5671(15) 00113-6$

Sutowo. (2000). Pariwisata Sebuah Model Pendekatan Strategi Pembangunan Nasional. Bahan Rapat Dengar Pendapat PHRI dengan Komisi IV DPR RI.

Sztompka, P. (2011). The Sociology of Social Change (Sosiologi Perubahan Sosial).Terjemahan Alimandan. Jakarta: Prenada.

Thelisa, M., \& others. (2018). Pengaruh Pariwisata Terhadap Kondisi Sosial Budaya Masyarakat Karimunjawa, Jawa Tengah. Jurnal Master Pariwisata (JUMPA), 228-239.

Todaro. (2000). Perkembangan Ekonomi, Edisi Kelima. Jakarta: Bumi Aksara.

Yoeti, O. A. (2008). Ekonomi Pariwisata: Introduksi, Informasi, Dan Implementasi. Jakarta (ID): Kompas. 